\title{
Forest loss and fire in the Dominican Republic during the 21st Century
}

\author{
Martínez Batlle, José Ramón(iD) \\ Facultad de Ciencias, Universidad Autónoma de Santo Domingo (UASD). Calle Alma \\ Mater, Santo Domingo, República Dominicana, Código Postal 10103
}

*This research was funded by Universidad Autónoma de Santo Domingo.
Email address: joseramon@geografiafisica.org (Martínez Batlle, José Ramón(D)) 


\title{
Forest loss and fire in the Dominican Republic during the 21st Century
}

\begin{abstract}
Forest loss is an environmental issue that threatens valuable ecosystems in the Dominican Republic (the DR). Although shifting agriculture by slash-andburn methods is thought to be the main driver of forest loss in the DR, empirical evidence of this relationship is still lacking. Since remotely sensed data on fire occurrence is a suitable proxy for estimating the spread of shifting agriculture, here I explore the association between forest loss and fire during the first 18 years of the 21st Century using zonal statistics and spatial autoregressive models on different spatio-temporal layouts. First, I found that both forest loss and fire were spatially autocorrelated and statistically associated with each other at a country scale over the study period. The hotspots were concentrated mainly in Cordillera Central, Sierra de Bahoruco, Los Haitises/Samaná Peninsula, and the northwestern and easternmost regions. Second, from regional scale analysis, I found no statistical association between forest loss and fire in the eastern half of the country, a region that hosts a large international tourism hub. Third, deforestation and fire showed a joint cyclical variation pattern of approximately four years up to 2013, and from 2014 onwards deforestation alone followed a worrying upward trend, while at the same time fire activity declined significantly. Fourth, I found no significant differences between the deforested area of small ( $<1 \mathrm{ha})$ and large ( $>1 \mathrm{ha})$ clearings of forest. I propose these findings hold potential to inform land management policies that help reduce forest loss, particularly in protected areas, mountain areas, and the vicinity of tourism hubs.
\end{abstract}

Keywords: deforestation, spatial autoregressive models, spatial autocorrelation, forest cover, forest change 


\section{Introduction}

Deforestation is a major concern for countries embracing the achievement of Sustainable Development Goal 15 (Department of Economic and Social Affairs of the United Nations Secretariat, 2009; UN System Task Team on the Post-

52015 UN Development Agenda, 2012). During the last decades, most countries have established reforestation programs to halt and reverse land degradation, but little effort has been made in preventing forest loss in preserved areas and secondary forests. In addition, a conceptual framework for developing indicators for the SDG 15 is missing, making it hard to assess whether or not the goal is being met (Hák et al., 2016).

A global assessment of 21st-Century forest cover change, derived from Landsat satellite observations, was published in 2013 and has since been updated yearly (Hansen et al., 2013). Several research teams used the outcomes of Hansen et al.'s work to assess the changes and trends of forest cover in different countries (Kalamandeen et al., 2018) and to explore the causes of deforestation (e.g., commodity-driven deforestation, shifting agriculture, and wildfires) Curtis et al. (2018). Although Tropek et al. (2014) commented that the study underestimates forest loss, Hansen et al. (2014) argued that such criticism is based on a misconception of the definition of forest used in their study.

Despite the ecological importance of the forest ecosystems in the Dominican Republic (hereafter, the DR) (Hager \& Zanoni, 1993; Cámara Artigas, 1997; Olson et al., 2001; Cano \& Veloz, 2012), comprehensive assessments of forest loss are rare. The available evidence suggests that there is a close relationship between forest loss and shifting agriculture, the latter driven mainly by slashand-burn practices (Cámara Artigas, 1997; Zweifler et al., 1994; Lloyd \& León, 2019; Wendell Werge, 1974; Ovalle de Morel \& Rodríguez Liriano, 1984; OEA, 1967; Tolentino \& Peña, 1998; Myers et al., 2004). Although the Ministry of Agriculture and the National Bureau of Statistics of the DR have conducted agricultural censuses, their efforts have failed to provide consistent and spatially 
dense data on the intensity and extent of shifting agriculture activity over the last decades (ONE, 1982, 2016). Therefore, even a simple correlation analysis between forest loss and agricultural activity is unfeasible with the available data published by government institutions. A further limitation is the fact that traditional regression analysis cannot to provide a systematic assessment of statistical association between variables that exhibit spatial autocorrelation, so spatial autoregressive models are needed (Anselin, 2013; Bivand et al., 2013b).

Considering these limitations, I explore here the statistical associations between fire and forest loss in the DR in the first 18 years of the 21st Century, using spatial autoregressive models applied to public data remotely and consistently collected. Specifically, and referring to those 18 years, I answer the following questions: 1) Was fire statistically associated with forest loss? 2) If so, was fire a suitable predictor of forest loss? 3) Was there a greater degree of association of fire with small forest clearings than with larger ones? 4) What did the spatio-temporal patterns of forest loss and fire look like? 5) Did a trend exist in either or both variables? I hypothesize that both fire and forest loss were significantly and increasingly associated over time, that fire was a suitable predictor of forest loss regardless of the size of the clearings, and that both fire and forest loss were spatially autocorrelated over the study period.

This is the first study providing empirical evidence of the association between fire and forest loss in the DR. I assert that the results obtained increase knowledge on spatio-temporal patterns of forest loss. In addition, the findings could assist decision-makers in assessing the achievement of the SDGs, and in designing more effective policies for the long-term planning of nature conservation and fire management.

\section{2. Materials and methods}

\subsection{Data download and preparation}

I used two types of datasets for this research: the collection of forest change layers from Hansen et al. (2013) and the fire point/hotspot locations from NASA 


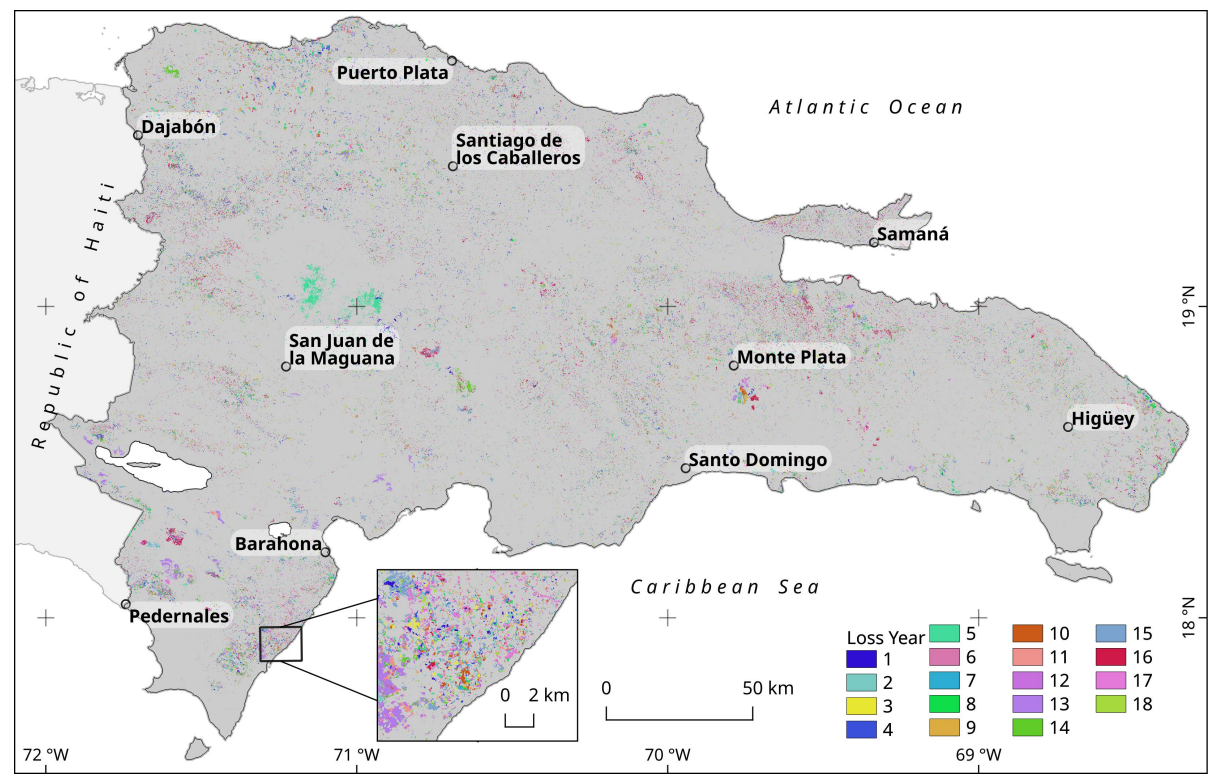

Figure 1: Loss year layer from 2001 to 2018 for the Dominican Republic, according to Hansen et al. (2013). Labelled points denote the location of some cities chosen as reference.

(2019a,b). From the forest change data, I used the loss year and the tree cover thematic tiles, which I downloaded from the Global Forest Change 2000-2018 data service (Hansen/UMD/Google/USGS/NASA, 2019). The tree cover tiles classify the land area in tree canopy densities for the year 2000 as a baselinewhere trees mean "vegetation taller than $5 \mathrm{~m}$ in height" - and the loss year tiles record the first year when the canopy reduced its density relative to the baseline

65 year. I stitched together the tiles from these datasets to form a seamless mosaic, and then warped the results on to the UTM/WGS84 datum, from which I later produced continuous maps of the DR mainland territory by masking out the ocean/lake areas (Fig. 1). Since these products do not distinguish plantations (e.g., oil palm and avocado plantations) from forest, I acknowledged this limitation when running exploratory analysis and building spatial models.

Moreover, the fire/hotspot data consisted of two products of the NASA's Fire Information for Resource Management System (FIRMS) processed by the 
University of Maryland, provided as point layer files by the LANCE/ESDIS platform, covering two overlapping periods of time (NASA, 2019a,b). The most 75 comprehensive dataset, labeled as "MODIS Collection 6 standard quality Thermal Anomalies / Fire locations" (MCD14ML), comprised fire data from 2000 to the present. The MODIS point location represents the center of a 1-km pixel containing one or more fires within the pixel. The second product, labeled as "VIIRS $375 \mathrm{~m}$ standard Active Fire and Thermal Anomalies product"

so (VNP14IMGTML), comprised locations of fires and thermal anomalies since 2012 up to the present time. In this dataset, each point represents the center of a $375 \mathrm{~m}$ pixel with at least one fire/thermal anomaly within the pixel. Therefore, given the improved spatial resolution of the VIIRS sensor, it records more fire points than the MODIS sensor.

85 The FIRMS source web service states that there are missing data at known dates in the MODIS product, but, since this issue affects a minimal portion of the time series, I decided to acknowledge it and use the entire dataset without applying missing data algorithms.

Most of the data points from both MODIS and VIIRS collections accounted for actual fires and thermal anomalies, but there were also noisy records (e.g., false positives) that could affect the results. Thus, I removed the persistent thermal anomalies records and other unrelated fire points, such as those originating from landfills with spontaneous combustion and industrial furnaces. For the purpose, I wrote an algorithm that spotted extremely dense point clusters.

${ }_{95}$ Afterward, I confirmed whether those clusters fell into industrial or landfill areas, by visually checking with base maps and satellite images. In most cases, those points were tagged as "other static land source" in the "Type" field of the datasets. Points that met at least the visual examination criteria were excluded from the dataset. In addition, I excluded all points with a confidence value of less than $30 \%$ in the MODIS collection, as well as those with a "low confidence" tag in the VIIRS collection. I refer to the resulting outcomes as "the noise-free versions of the fire points datasets" or simply "the noise-free versions" (Fig. 2). 


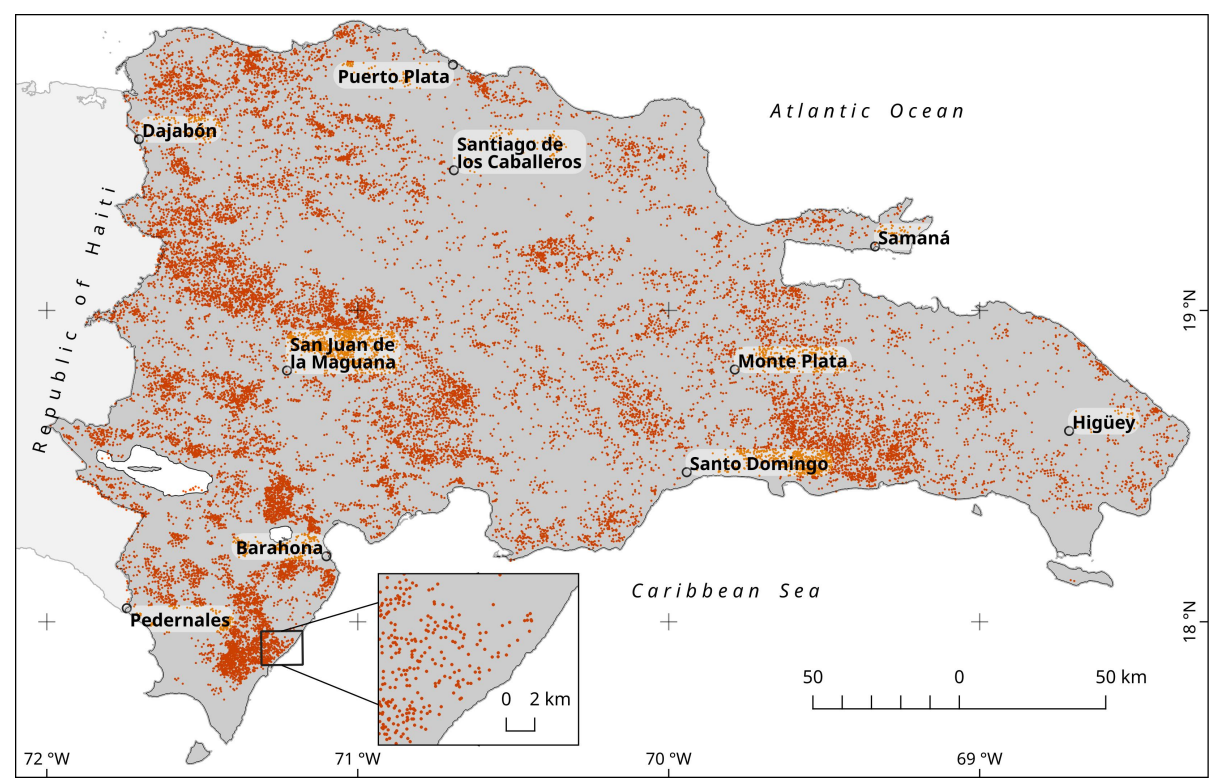

Figure 2: MODIS dataset from 2001 to 2018 for the DR mainland. This is a noisefree version of the original dataset, which excludes unrelated fire points (e.g., burning landfills and industrial furnaces). See text for details.

Last, I applied a mask comprising the DR land area to each dataset used in the study. I generated the mask by combining a shapefile containing the international DR border, downloaded from ONE (2015), with the datamask included in the forest change dataset. Permanent water bodies were excluded from the analysis, using their extent area as seen in the 2000 Landsat ETM+ imagery. For consistency reasons, I reprojected the point data files to conform to the UTM/WGS84 datum.

\subsection{Spatio-temporal approaches}

I used two different spatio-temporal approaches to answer the questions posed in this study, which I refer to as "the long-term approach" and "the annual approach", respectively. In both approaches, I applied spatial statistics techniques to explore association patterns between forest loss and fire, using statistical summaries generated from zonal grids and value layers. 


\subsubsection{Long-term approach}

In this approach, I assessed the association between forest loss and fire in two overlapping periods - 2001-2018 and 2012-2018 - using a zonal grid. I focused the analysis on the areas with $25 \%$ or higher tree cover in year 2000 as a baseline, which I refer to as "forest cover in 2000", or simply "forest cover" (Fig. A1). The zonal grid consisted of 482 adjacent hexagons, each with a nominal surface area of $100 \mathrm{~km}^{2}$ and having at least $45 \%$ of its area on mainland territory (Fig. A1). With this setting, the total area of the zonal grid was approximately $46,200 \mathrm{~km}^{2}$, which is indeed slightly smaller than the DR territory (approximately $48,400 \mathrm{~km}^{2}$ ).

To generate the fire data layers, I used the noise-free versions of the MODIS and VIIRS datasets separately as inputs. From the former, I filtered the records for the period 2001-2018, and, from the latter, those for the period 2012-2018. Afterward, for each period, I selected the fire points falling into forest stands with a canopy closure equal to or greater than $25 \%$, which I generated from the year 2000 tree cover raster layer. Then, I computed the number of fire points from both datasets for each hexagon of the zonal grid. Last, I divided the number of points by the cell area in square kilometers, and then again by the number of years of each of the two periods of analysis, from which I obtained two data fields, one for each period of analysis, containing the average density of fire points per square kilometer per year (hereafter, fire density).

Moreover, I generated two raster layers of forest loss, one for each period of analysis, by reclassifying twice and separately the loss year raster. The values from 1 to 18 and from 12 to 18 were then reclassified into one pooled category of forest loss for the periods 2001-2018 and 2012-2018, respectively. Thereafter, for each hexagon of the zonal grid, I computed the surface area of forest loss per unit area by dividing the forest loss surface area by the corresponding cell size, and then again by the number of years of each period, to obtain two data fields, one for each period of analysis (i.e., 2001-2018 and 2012-2018) of average

forest loss per unit area per year. 
While the long-term approach provides a useful summary of the relationships between fire density and forest loss for the period analyzed, most of the trends, cyclical variation, and other insightful patterns would remain unknown without an annual analytical approach.

\subsubsection{Annual approach}

For this approach, I analyzed temporal trends and statistical association between forest loss and fire on an annual basis. In particular, I focused on assessing the association between those variables considering the size of the forest clearings, using both absolute values and zonal statistics metrics.

To obtain the absolute forest loss data, I generated 18 maps of annual forest loss, one per each year of the study period, using the loss year raster as a source. From each map, I grouped the connected cells belonging to the same patch using the Queen's case neighborhood, and then calculated the surface area of the clumped patches. Afterward, using Boolean operators, I generated 18 annual forest loss maps of "small forest clearings", made up of patches less than 1 ha in size, and 18 maps of "medium- and large-sized forest clearings" (or simply "large clearings"), consisting of patches larger than 1 ha in size. Then, I computed the annual forest loss separately by size of clearing, summing up the surface area values of the individual patches of each loss map. Finally, I assessed the homogeneity of annual average values using paired $t$-test and Wilcoxon test.

In addition, I performed zonal statistic analyses, by summarizing annual forest loss and fire density over a regular hexagon grid of 253 hexagons, each of which had a maximum area of approximately $195 \mathrm{~km}^{2}$. I used a regular grid with larger cells than those of the grid used in the long-term approach, to reduce the skewness of the variables summarized or, in a best-case scenario, to improve adherence to normality assumption.

To perform the zonal statistics analysis of forest loss, I used separate metrics for large and small clearings. For large clearings, I used the relative area of annual forest loss (measured in $\mathrm{km}^{2}$ per $100 \mathrm{~km}^{2}$ ), since that metric is suitable for characterizing the deforestation activity on a given cell. For small clearings, 
density of patches (measured in number of patches per $100 \mathrm{~km}^{2}$ ) was used, since the relative area may be irrelevant for summarizing small clearings on a given cell.

To obtain the yearly subsets of fire points, I used the noise-free versions of MODIS and VIIRS datasets from two overlapping periods, 2001-2018 and 20122018, respectively. I generated annual maps of fire points using the date field of the datasets. Then, from the annual maps of large clearings, buffer zones were created around the patches at a maximum distance of $2.5 \mathrm{~km}$. Afterward, I generated the corresponding annual subsets of fire points, selecting only those falling within the patches and/or their buffer zones (Fig. B1). Last, I summarized, over the hexagon grid, the yearly density of fire points per $100 \mathrm{~km}^{2}$.

\subsection{Exploratory spatial data analysis and spatial modeling}

For both the long-term and annual approaches, I conducted exploratory spatial data analysis (ESDA) and fitted several spatial models using the maximum likelihood estimation method. First, I assessed the normality of the variables using Shapiro-Wilk tests and QQ plots, and applied Tukey's Ladder of Power transformations to those variables departing from normality before performing spatial analysis (Mangiafico, 2019).

Afterward, for each of the grids used in this study, I created neighbour objects between hexagons based on the criterion of contiguity. As expected, each hexagon became the neighbour of six other contiguous hexagons, except for those located at the edge of the grid. Then, I defined spatial weights from the neighbour objects using the "W-style"-row standardization-, in which the weights of all the neighbour relationships for each areal unit summed 1.

As a prerequisite for spatial modeling, I tested whether fire density and forest loss variables showed spatial autocorrelation, using Moran scatterplots and Moran's I tests. I also generated local indicators of spatial association maps (hereafter "LISA maps"), to represent high-high and low-low clusters of fire density and forest loss across the DR (Bivand et al., 2013b,a; Bivand \& Piras, 2015; Bivand et al., 2017; Bivand \& Wong, 2018; Anselin, 1995; Anselin 
\& Rey, 2010; Anselin, 1996). A high-high cluster-hereafter HH cluster-is a group of cells in which high values are surrounded primarily by other high values. Conversely, a low-low cluster-hereafter LL cluster - is a group of cells with low values surrounded by other low values.

All the models generated for both the long-term and the annual approaches used fire density as a predictor variable and forest loss as a response variable. Since both variables showed significant patterns of spatial autocorrelation, I analyzed the statistical association between them using spatial models. In the long-term approach, I evaluated the prediction performance of spatial lag and spatial error models. The most suitable model for each approach was chosen based on the results of the Lagrange Multiplier diagnostic for spatial dependence in linear models, the heteroskedasticity of residuals tests, and the Akaike information criterion (AIC) (Bivand et al., 2013b; Sakamoto et al., 1986; Breusch \& Pagan, 1979; Anselin, 2013; LeSage, 2015). In the annual approach, I generated yearly spatial error models to assess the statistical association between fire and forest loss. In general, and unless otherwise indicated, for all statistical tests, I used a significance level $\alpha=0.05$, and for error estimation I used a $95 \%$ confidence level.

The final stage was to produce all the results, including statistical sum225 maries, maps, and graphics in QGIS and R programming environment, using parallel computing packages for generating the zonal statistics outcomes, as well as multiple packages for data visualization and spatial modeling (QGIS Development Team, 2020; R Core Team, 2020; Pebesma, 2018, 2019; Kuhn et al., 2019; Greenberg \& Mattiuzzi, 2018; Weston, 2019; Hijmans, 2019; Venables \& Ripley, 2002; Tennekes, 2018; Wickham, 2017).

\section{Results}

\subsection{Long-term approach}

The surface areas of forest loss relative to the forest cover in the year 2000, were approximately $3,100 \mathrm{~km}^{2}$ and $1,500 \mathrm{~km}^{2}$ during the periods $2001-2018$ and 

2012-2018, respectively, which represent c. $7 \%$ and $3 \%$ of the entire grid analyzed (Table1). Moreover, during the same periods, the MODIS and VIIRS sensors recorded almost 11,600 and 25,200 points within forest cover areas, respectively.

Table 1: Forest loss and number of fire points within forest cover, summarized using a grid of 482 hexagons, for the periods 2001-2018 and 2012-2018. The baseline year for the forest is $2000^{\dagger}$.

\begin{tabular}{|c|c|c|}
\hline Attribute & $\begin{array}{c}\text { Period 2001-2018 } \\
\text { (fire data from MODIS) }\end{array}$ & $\begin{array}{c}\text { Period 2012-2018 } \\
\text { (fire data from VIIRS) }\end{array}$ \\
\hline Total number of fire points & 11,666 & 25,231 \\
\hline $\begin{array}{l}\text { Average number of fire } \\
\text { points per } 100 \mathrm{~km}^{2}\end{array}$ & 25.13 & 54.86 \\
\hline $\begin{array}{l}\text { Average number of fire } \\
\text { points per } 100 \mathrm{~km}^{2} \text { per year }\end{array}$ & 1.4 & 7.84 \\
\hline $\begin{array}{l}\text { Maximum number of fire } \\
\text { points per } 100 \mathrm{~km}^{2} \text { per year }\end{array}$ & 13.22 & 67.29 \\
\hline $\begin{array}{l}\text { Total forest loss area in } \mathrm{km}^{2} \\
\text { (approximate percentage } \\
\text { relative to the entire grid) }\end{array}$ & $3135.22(6.8 \%)$ & $1461.42(3.2 \%)$ \\
\hline $\begin{array}{l}\text { Average forest loss area } \\
\left(\mathrm{km}^{2}\right) \text { per } 100 \mathrm{~km}^{2}\end{array}$ & 6.72 & 3.13 \\
\hline $\begin{array}{l}\text { Average forest loss area } \\
\left(\mathrm{km}^{2}\right) \text { per } 100 \mathrm{~km}^{2} \text { per year }\end{array}$ & 0.37 & 0.45 \\
\hline $\begin{array}{l}\text { Maximum forest loss area } \\
\left(\mathrm{km}^{2}\right) \text { per } 100 \mathrm{~km}^{2} \text { per year }\end{array}$ & 1.82 & 3.21 \\
\hline
\end{tabular}

$\dagger$ The values of this table were summarized using zonal statistics techniques relative to a hexagonal grid. Thus, actual values of the entire DR are slightly larger, since forest loss patches and fire points outside the grid were ignored.

Most of the DR mainland territory experienced low levels of forest loss from 2001 to 2018 (i.e., $<6 \mathrm{~km}^{2}$ per $100 \mathrm{~km}^{2}$ ). However, high levels of forest loss were common in several mountain ranges and protected areas, such as Los Haitises karst region, Samaná Peninsula, Sierra de Bahoruco, and the Cordillera Central southern and northwestern borders (see Fig. 3-A). It should be particularly emphasized that inaccessible areas in Los Haitises, Sierra de Bahoruco and south245 ern Cordillera Central, reached worrisome records of forest loss greater than $25 \mathrm{~km}^{2}$ per $100 \mathrm{~km}^{2}$. Additionally, the Eastern Region-Punta Cana and its 


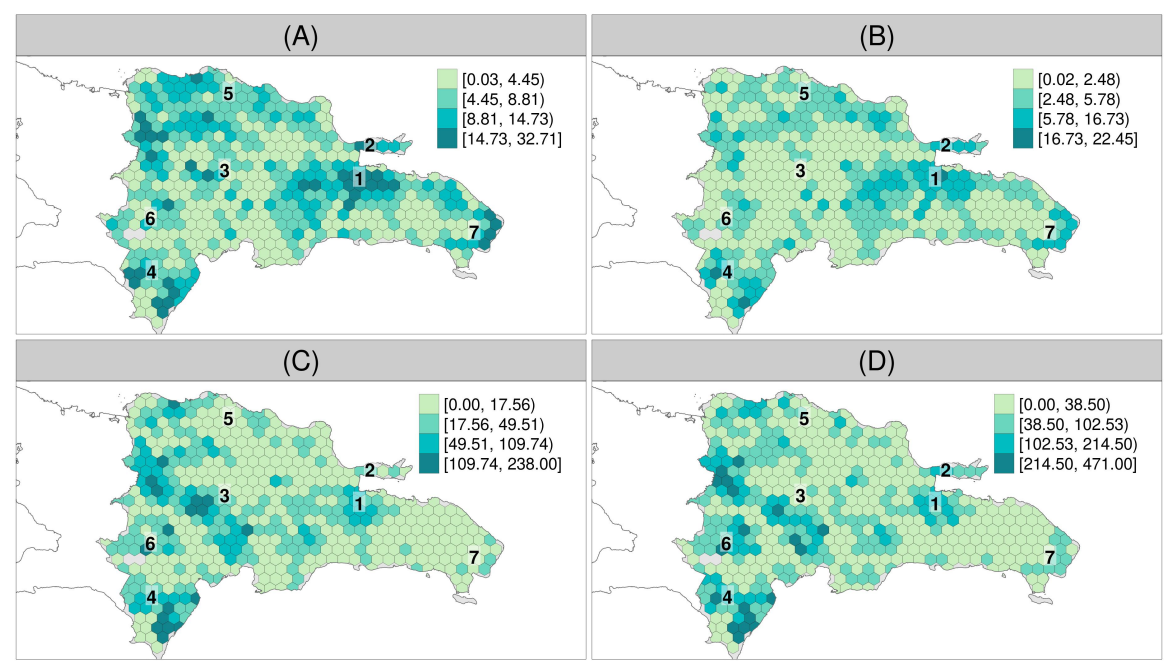

Figure 3: Forest loss (in $\mathrm{km}^{2}$ per $100 \mathrm{~km}^{2}$ ) for the periods (A) 2001-2018 and (B) 20122018. Number of fire points per $100 \mathrm{~km}^{2}$ within forest cover for the periods 2001-2018 using MODIS dataset (C), and 2012-2018 using VIIRS dataset (D). The baseline year for forest cover is 2000. Reference locations: 1 Los Haitises; 2 Samaná Peninsula; 3 Cordillera Central mountain range; 4 Sierra de Bahoruco; 5 Cordillera Septentrional; 6 Sierra de Neyba; 7 Eastern Region.

surroundings, where tourism development has grown steadily since the 1990sexperienced high rates of forest loss during this period. Moreover, between 2012 and 2018, widespread forest loss occurred in Los Haitises and the eastern border of Cordillera Central (Fig. 3-B).

Furthermore, the density of fire points showed a distribution pattern similar to that of forest loss. In both periods, 2001-2018 and 2012-2018, high densities of fire points were fairly common in many areas, such as the southern margin of Cordillera Central, Sierra de Bahoruco, Sierra de Neyba, and Los Haitises, with more than 30 and 65 fires per $100 \mathrm{~km}^{2}$ detected by MODIS and VIIRS, respectively (Figs. 3-C and 3-D).

Since both fire density and forest loss departed significantly from normality, I transformed them using the Tukey's Ladder of Powers method. As a result, forest loss fulfilled the normality assumption and fire density reduced its skewness. 
Afterward, I evaluated the spatial autocorrelation of the transformed variables using LISA maps, Moran's I tests, and Moran scatterplots, which consistently showed positive autocorrelation patterns (Table A1, Figs. 4 and A2).

The prevalence of $\mathrm{HH}$ clusters indicates that forest loss was notably widespread during the periods 2001-2018 and 2012-2018 in Los Haitises, Sierra de Bahoruco, Samaná Peninsula, and the Eastern Region (Figs. 4-A and 4-B). Furthermore, the analysis of the 2012-2018 period exclusively shows that HH clusters were almost absent in the northwestern and southern margins of Cordillera Central, and in western Cordillera Septentrional as well (Fig. 4-B). Finally, LL clusters of forest loss represented areas of intensive farming and/or where forest cover was absent in 2000.

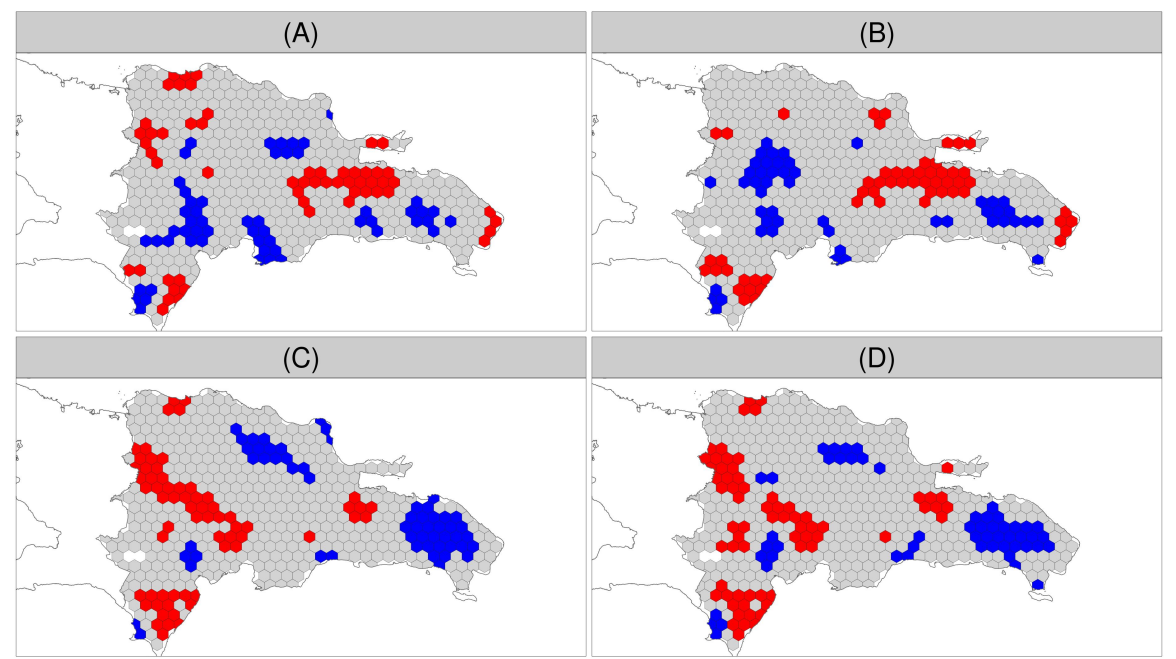

Figure 4: LISA maps of forest loss per unit area averaged per year for the periods (A) 2001-2018 and (B) 2012-2018, and fire points per $\mathrm{km}^{2}$ averaged per year within forest cover for the same periods using MODIS (C) and VIIRS (D) datasets. The Tukey's Ladder of Powers transformed versions of the variables were used as inputs in all cases. Each hexagon was classified either as HH cluster (red), LL cluster (blue), or no significant spatial association (grey) regarding the corresponding variable.

Moreover, HH clusters of fire density were notably widespread in the southern margin of Cordillera Central, Los Haitises, western Cordillera Septentrional, 
Sierra de Neyba, and Sierra de Bahoruco (Figs. 4-C and 4-D). There is a noticeable high degree of agreement between forest loss and fire density LISA maps in Los Haitises, Sierra de Bahoruco, and other areas, suggesting that an association exists between these variables. A notable exception is the Eastern Region, where HH clusters of forest loss were not correspondingly matched by HH clusters of fire points.

I fitted spatial lag and spatial error models to predict forest loss as a function of fire density for both 2001-2018 and 2012-2018 periods. To generate the models of the first period, I used forest loss per unit area per year from 2001 to 2018 as the dependent variable, and MODIS fire points per square kilometer per year of the same period as the independent variable. For the second period, I used forest loss per unit area per year from 2012 to 2018 as the dependent variable, and VIIRS fire points per square kilometer per year of the same period as the independent variable. In all cases, the Tukey's Ladder of Powers transformed versions of the variables were used as inputs.

The results of the Lagrange Multiplier tests indicated that a spatial error specification was suitable for the data of the 2001-2018 and 2012-2018 periods (Table A2). The relevant statistics of the spatial error models fitted are summarized in Table 2. Both the coefficient and the intercept estimates for each model were positive and significant in the spatial error models $(p \lll 0.01)$. In particular, the intercept estimate of the 2012-2018 model, which used VIIRS fire density as an explanatory variable of forest loss, was remarkably high. AIC values were lower in spatial error models than those of their equivalent lineal models. In addition, the Breusch-Pagan and Moran's I tests showed no trace of heteroskedasticity and spatial autocorrelation of residuals, respectively.

Lastly, considering only fire as a driver of forest loss, on average, each fire point detected by the MODIS sensor between 2001 and 2018 and by the VIIRS sensor between 2012 and 2018 was associated with 1.5 ha and 3 ha of forest loss, respectively, implying a substantial effect size of fire density on forest loss in the DR. 
Table 2: Spatial error model fitting results of forest loss as a function of fire density for the periods 2001-2018 (MODIS fire data) and 2012-2018 (VIIRS fire data)

\begin{tabular}{|l|r|r|}
\hline \multicolumn{1}{|c|}{$\begin{array}{c}\text { Summary } \\
\text { statistic }\end{array}$} & $\begin{array}{c}\text { FORESTLOSS0118 } \\
\text { FIRESMODIS }\end{array}$ & $\begin{array}{c}\text { FORESTLOSS1218 } \\
\text { FIRESVIIRS }^{\dagger}\end{array}$ \\
\hline $\begin{array}{l}\text { Intercept (Std. Error; } \\
\operatorname{Pr}(>|z|))\end{array}$ & $0.099(0.005 ; p \lll 0.01)$ & $0.173(0.008 ; p \lll 0.01)$ \\
\hline $\begin{array}{l}\text { Coefficient (Std. Error; } \\
\operatorname{Pr}(>|z|))\end{array}$ & $0.250(0.015 ; p \lll 0.01)$ & $0.247(0.014 ; p \lll 0.01)$ \\
\hline$\lambda($ LR test value, $p$-value) & $0.732(243.26 ; p \lll 0.01)$ & $0.740(252.43 ; p \lll 0.01)$ \\
\hline $\begin{array}{l}\text { Moran's } I \text { test for residuals } \\
(p \text {-value })\end{array}$ & $-0.002(p=0.5)$ & $-0.016(p=0.69)$ \\
\hline $\begin{array}{l}\text { Breusch-Pagan test statistic } \\
(p \text {-value })\end{array}$ & $0.46(p=0.5)$ & $3.58(p=0.06)$ \\
\hline $\begin{array}{l}\text { AIC (AIC for standard linear } \\
\text { model })\end{array}$ & $-2183.9(-1942.7)$ & $-1865.5(-1615.1)$ \\
\hline \multicolumn{2}{|c|}{0.60} & 0.62 \\
\hline
\end{tabular}

loss per unit-area averaged per year of the periods 2001-2018 and 2012-2018, respectively. FIRESMODIS and FIRESVIIRS stand for the transformed versions of number of fires per $\mathrm{km}^{2}$ averaged per year, detected by the MODIS sensor (2001-2018) and by the VIIRS sensor (2012-2018), respectively.

\subsection{Annual approach}

Using a paired $t$-test, I found no significant differences between proportional

deforestation area originated from small and large clearings $-t=-2.08, d f=17$, $p=0.053$. Furthermore, in several years of the study period $(2001,2003,2011)$, the total area of deforestation originated from small clearings was greater than that from large clearings (see Fig. 5).

The yearly average forest loss area recorded in large clearings was $0.2 \mathrm{~km}^{2} / 100 \mathrm{~km}^{2}$, and reached a maximum of nearly $0.4 \mathrm{~km}^{2} / 100 \mathrm{~km}^{2}$. Further, the yearly average number of small clearings was 237 patches per $100 \mathrm{~km}^{2}$, and the maximum reached approximately 400 patches per $100 \mathrm{~km}^{2}$ (see Figs. 6.A-B and B2.A-B). Regarding fire density, the MODIS sensor detected nearly two fire points per $100 \mathrm{~km}^{2}$ per year on average, and a maximum of 3.5 points per $100 \mathrm{~km}^{2}$ per year. Finally, the VIIRS sensor detected, from 2012 to 2018, 9 fire points per $100 \mathrm{~km}^{2}$ per year on average, and 12 fire points at most (see Figs. 


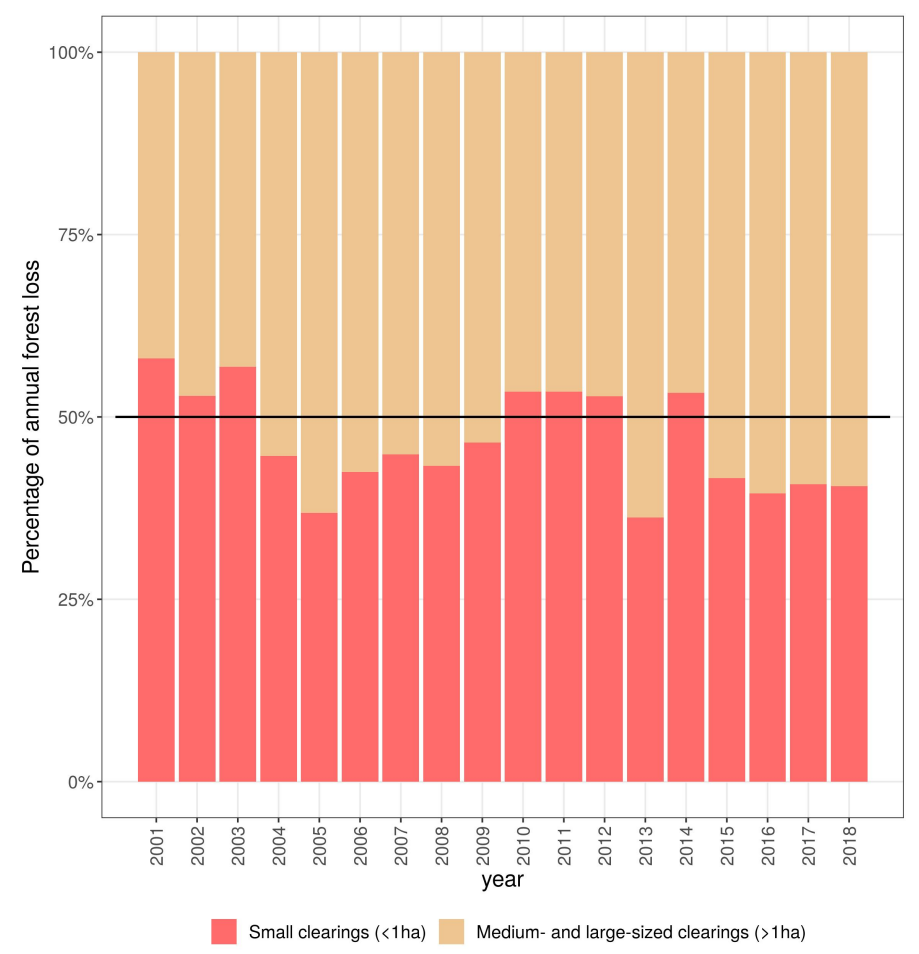

Figure 5: Composition of annual forest loss area by size of clearing

6.C-D and B2.C-D). The higher hotspot detection rate of the VIIRS sensor compared to that of the MODIS sensor is due to its higher spatial resolution.

Forest loss activity and fire occurrence showed a joint four-year cyclical pattern of variation during most of the period investigated. However, the time-series of forest loss and fire activity diverge considerably from each other, starting in 2014. In particular, forest loss increased rather steeply from 2014 to 2017, whereas the number of fire points decreased significantly during the same period (Fig. 6). Hence, this is the first time in the past two decades in which fire and forest loss followed diverging trends nationwide.

Regarding spatio-temporal features, both forest loss and fire density showed patterns of cyclical variation of their spatial autocorrelation, and featured multiple spatial layouts of HH clusters and LL clusters in shifting locations throughout the DR over the period under investigation. Moran's I tests, which were 


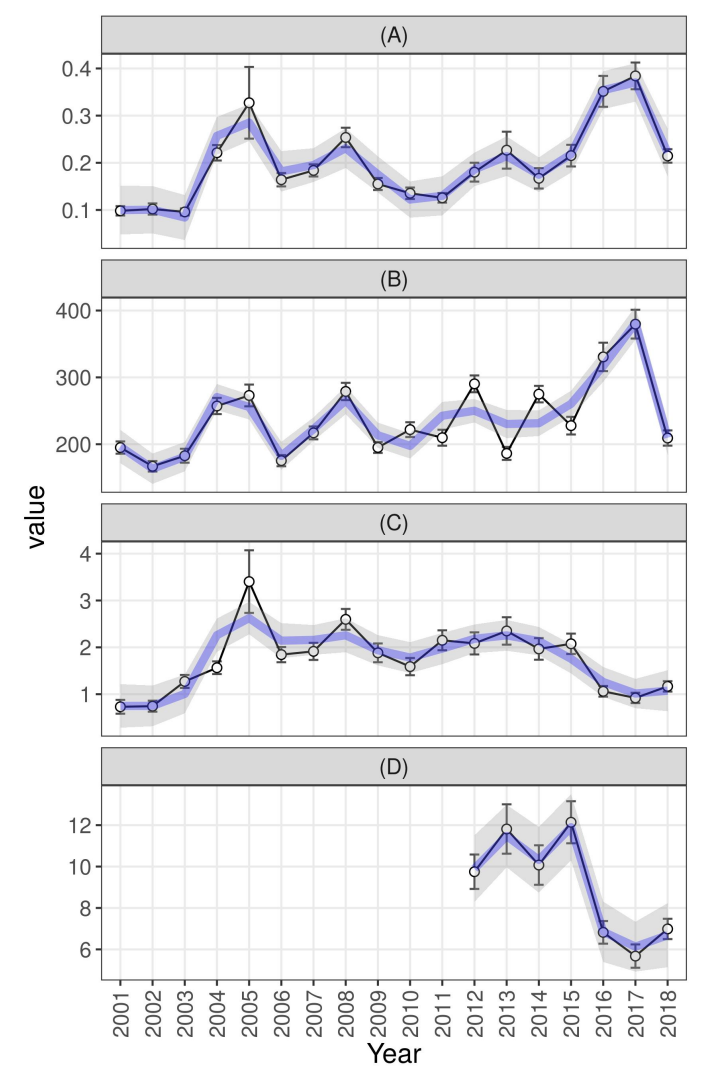

Figure 6: Yearly averages per $100 \mathrm{~km}^{2}$ of (A) Forest loss area $\left(\right.$ in $\left.\mathrm{km}^{2}\right)$ of large clearings ( $>1$ ha in size); (B) Number of small clearings ( $<1$ ha in size); (C) and (D) Number of fire points remotely sensed by MODIS and VIIRS sensors in or around forest loss patches

applied to the transformed versions of the variables, yielded significant results for every year of the study period. In addition, the Moran's $I$ test statistic showed a cyclical and varied pattern for all the variables analyzed over the study period (Fig. 7).

Concerning patterns of forest loss, the HH clusters were concentrated mainly in five locations during the study period: Los Haitises-Samaná Peninsula, Cordillera Central, Sierra de Bahoruco, and Northwestern and Eastern Regions, the last being the largest tourism hub of the DR - including the resort town of 


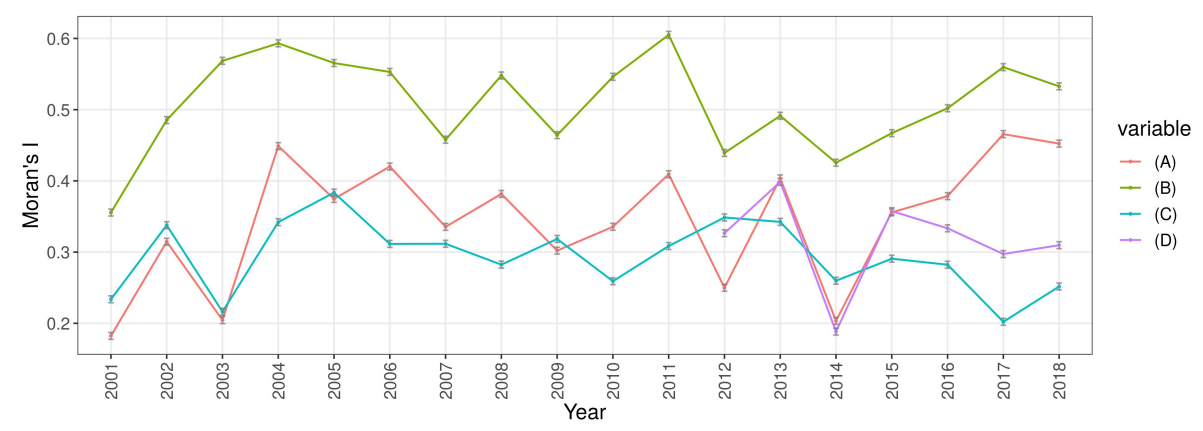

Figure 7: Moran's $I$ evolution for the transformed versions of yearly averages per $100 \mathrm{~km}^{2}$ of (A) Forest loss area of large clearings ( $>1$ ha in size); (B) Number of small clearings ( $<1$ ha in size); (C) and (D) Number of fire points located inside or around forest loss patches, remotely recorded by MODIS and VIIRS sensors, respectively

Punta Cana and other tourist destinations (Figs. 8, 9, B3 and B4). The Eastern Region, in particular, showed very distinctive spatio-temporal patterns of forest loss over the study period; therefore, I analyzed that region separately.

During the three-year period 2001-2003, HH clusters of both small and large forest clearings were concentrated in Los Haitises-Samaná Peninsula and at the southern and northern ends of western DR. From 2004 to 2012, large forest clearings were significantly concentrated in the northwest of the DR - which peaked in 2004, and in the periods 2006-2008 and 2010-2011, in southern Cordillera Central and Sierra de Bahoruco. In addition, HH clusters of small clearings were widespread in Los Haitises in 2003, 2005, 2007-2008, and 2010. Subsequently, during the period 2013-2018, HH clusters of both large and small clearings were concentrated in Los Haitises and in Samaná Peninsula, as well as in western and southeastern portions of Cordillera Central and Sierra de Bahoruco. Of note was widespread deforestation in Los Haitises and its southern end, which comprises an active oil palm plantation. These hotspots are shown on the LISA maps by large HH clusters of small clearings during the period 2013-2014, as well as by HH clusters of both large and small clearings in the period 2017-2018. 

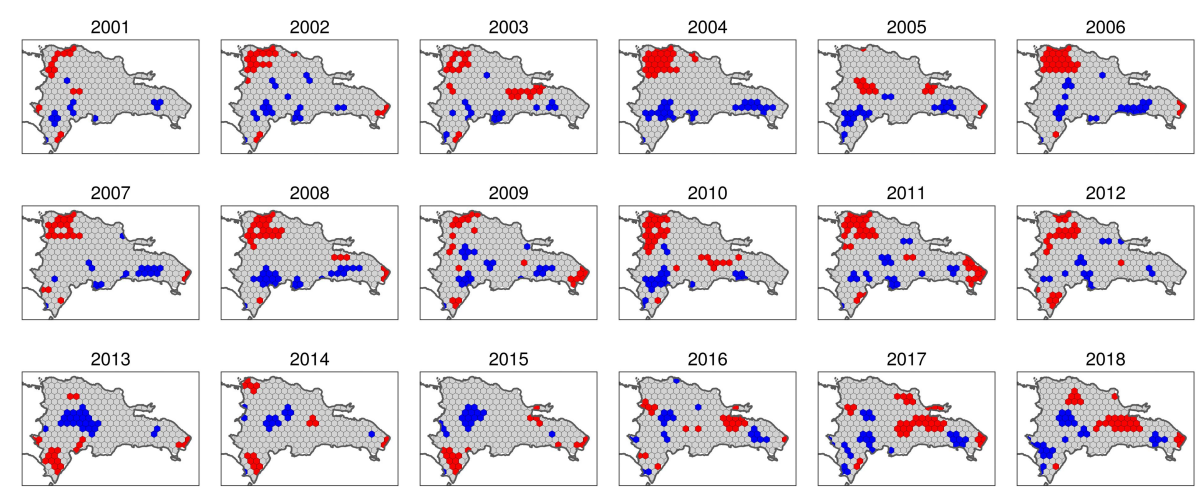

Figure 8: Yearly LISA maps of transformed forest loss density data of large clearings.

Red represents HH clusters, blue depicts LL clusters, and grey shows no significant spatial association.
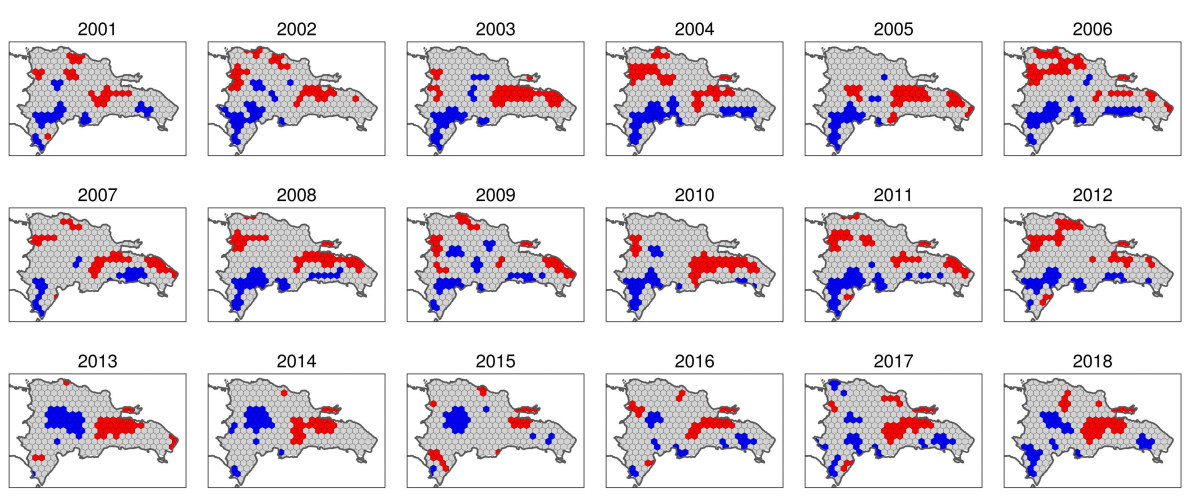

Figure 9: Yearly LISA maps of transformed forest loss density data of small clearings. Same legend as in Fig 8.

In addition, concerning the Eastern Region, $\mathrm{HH}$ clusters of large clearings began to develop in 2002 and stopped in subsequent years, then emerged intermittently from 2005 onwards, showing peaks of activity in 2009 and 2011 and a steady increase between 2013 and 2018. Notably, HH clusters of small clearings were detected in this region in 2003, in 2005-2009, and in years 2011 and 2013, but no new clusters of this type were observed in subsequent years.

Regarding fire density, during the entire period investigated, HH clusters were concentrated especially in the western half of the DR, particularly in the 
Northwestern Region, Sierra de Bahoruco, and Cordillera Central (Figs. 10, 11, B5 and B6). Also, during both the first years and in the middle of the period, HH clusters were present in Los Haitises and Samaná Peninsula.
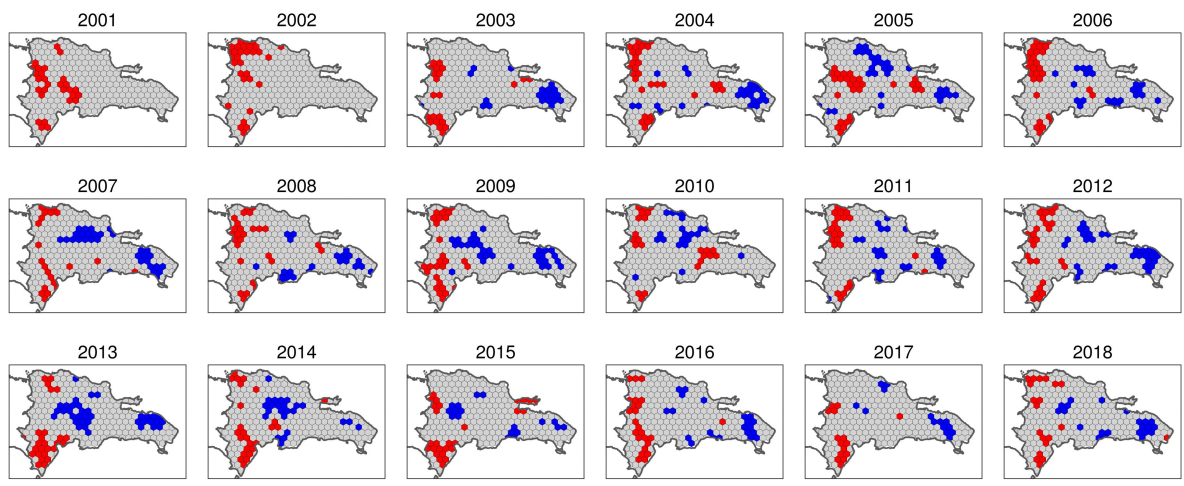

Figure 10: Yearly LISA maps of transformed MODIS fire density data. Same legend as in Fig 8.
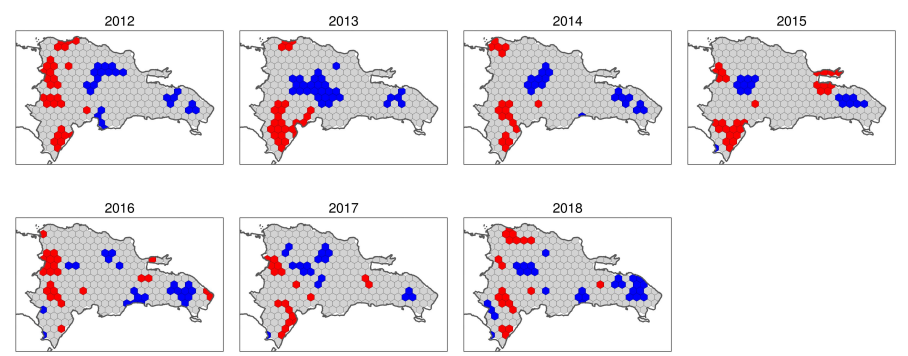

Figure 11: Yearly LISA maps of transformed VIIRS fire density data. Same legend as in Fig 8.

As shown in the LISA maps of MODIS fire density, the spatial patterns of fire density slightly resembled those of forest loss over the period under study (Fig. 10). However, the degree of agreement between forest loss and fire density was greater in the Western and Central Regions - Sierra de Bahoruco, Northwestern Region, Cordillera Central - than in the eastern half of the country-Los Haitises and the Eastern Region. Particularly, although the eastern half showed extensive forest loss activity, few $\mathrm{HH}$ clusters of fire density were recorded in 
this region during the period under investigation. In fact, during the six-year period 2013-2018, HH clusters of fire completely disappeared from the Eastern

375 Region (Figs. 11 and B6). Hence, fire activity showed a diverging trend in relation to that of deforestation in Los Haitises and the Eastern Region.

In addition, three remarkable features regarding the distribution of $\mathrm{HH}$ clusters of fire density merit mention in this section. (Figs. 10, 11, B5 and B6). The first is a large concentration of HH clusters in 2005 over southern Cordillera Central, related to an uncontrolled wildfire that devastated almost $80 \mathrm{~km}^{2}$ of pine forest. As a result, more than 100 fire points per $100 \mathrm{~km}^{2}$ were reached, which is a historical record. Second, for three years in a row - 2013, 2014, 2015 - both MODIS and VIIRS sensors detected a high concentration of hotspots over Sierra de Bahoruco, attributable to multiple wildfires that swept large areas of different types of mountain forests during those years. Third, in 2014 and 2015, both sensors detected a relatively high number of fire points in Valle Nuevo, southern Cordillera Central, which are depicted in Fig. B6 as HH clusters, and which are also consistent with the fire history of the area.

Finally, the spatial error models yielded consistent results for forest loss as a function of fire density (Table 3). The main finding was that, when modeling the variables over the entire grid - i.e., nationwide analysis - fire density significantly associated with forest loss, which is consistent with the results of the longterm approach. Particularly, both fire density coefficient and intercept were significant in every annual model, regardless of the size of deforestation clearings, whether large or small. Moreover, regional subsets showed that fire density was a suitable predictor of forest loss most of the time in Western and Central regions, whereas in Los Haitises-Samaná Peninsula and the easternmost region, fire density failed as a predictor of forest loss for many years. 
Table 3: Number of years in which the coefficients of the annual spatial error models were not significant, considering the entire grid and different regional subsets.

\begin{tabular}{|l|l|l|}
\hline $\begin{array}{l}\text { Variables of the models } \\
\text { (transformed versions) }\end{array}$ & Regional subset (see Fig. 12) & $\begin{array}{l}\text { Number of years } \\
\text { parenthesis) }\end{array}$ \\
\hline \multirow{4}{*}{$\begin{array}{l}\text { Forest-listing in } \\
\text { large clearings vs. MODIS } \\
\text { fire density }\end{array}$} & Entire grid & - \\
\cline { 2 - 3 } & Western & - \\
\cline { 2 - 3 } & Central & 1 year $(16)$ \\
\cline { 2 - 3 } & Los Haitises-Samaná & 11 years $(1,2,7,9-14,16,17)$ \\
\cline { 2 - 3 } $\begin{array}{l}\text { Forest-loss per unit-area in } \\
\text { small clearings vs. MODIS } \\
\text { fire density }\end{array}$ & Eastern & 9 years $(1-4,7,10,15-17)$ \\
\hline & Entire grid & - \\
\cline { 2 - 3 } & Cestern & - \\
\cline { 2 - 3 } & Central & 7 years $(4,12,16)$ \\
\cline { 2 - 3 } & Los Haitises-Samaná & 15 years $(1-12,12,7,12,17)$ \\
\cline { 2 - 3 } & Eastern & \\
\hline
\end{tabular}

${ }^{\dagger}$ Number of years with non-significant coefficient at $\alpha=0.01$

(A)

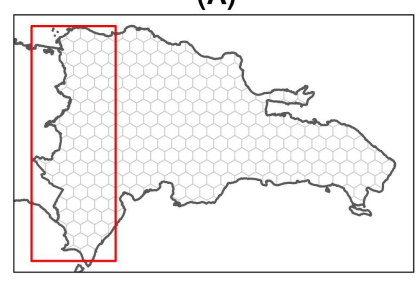

(C)

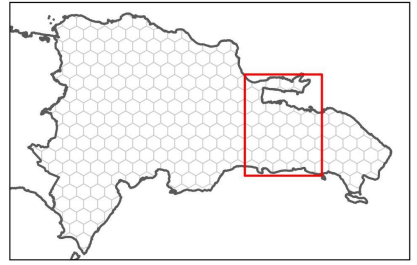

(B)

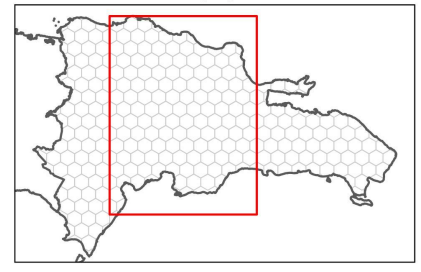

(D)

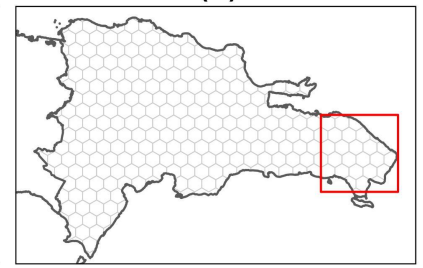

Figure 12: Regions for annual model analyses. (A) Western, (B) Central, (C) Los Haitises-Samaná, and (D) Eastern.

\section{Discussion}

I hypothesized that fire and forest loss were significantly associated during the first 18 years of the 21st Century in the DR, and that fire was a suitable predictor of forest loss, regardless of the size of the forest clearings. The evidence found in the present study supports this hypothesis consistent with other studies 
that found a significant association between forest loss and slash-and-burn agriculture (Zweifler et al., 1994; Lloyd \& León, 2019; Wendell Werge, 1974; Myers et al., 2004). Moreover, the association between fire and forest loss is particularly consistent in the western half of the DR, which is likely due to the more pronounced dry season in that region and to the presence of large mountain systems, i.e., Cordillera Central, where shifting agriculture is widespread.

However, the evidence also suggests that, in the eastern half of the country, which includes Los Haitises and the easternmost region, fire was not a suitable predictor of forest loss. Two conjectures may explain this finding: 1) Frequent cloudy skies over the region, which may prevent optical sensors-i.e., MODIS and VIIRS - from recording fire hotspots; 2) Factors other than fire that may ${ }_{415}$ drive forest loss, such as commodity-driven agriculture, shifting agriculture by means of downing vegetation without burning - or by indeed performing burns but with little impact on forest cover - and expansion of tourism infrastructure facilities. The first conjecture is unlikely to explain the observed pattern, since fire activity in cloudy conditions, considered on an annual average basis, would have little effect as a driver of pervasive deforestation. The second conjecture provides a more likely explanation for deforestation peaks not associated with fires, since it fits quite well with the tree cover decimation mechanisms that are typically used in this part of the DR, i.e., forest clearing to expand shifting agriculture driven primarily by subsistence needs. Since there are many contextual differences between Los Haitises and the easternmost tourism hub, I discuss the implications of holding this hypothesis true for each area separately.

In Los Haitises National Park, shifting agriculture was likely the most suitable driver of deforestation, since it is a well-documented concern in this protected area (Gesto de Jesús, 2016; Dirección Nacional de Parques, 1991). Shift430 ing agriculture is commonly driven by slash-and-burn systems, but in this case the "burn" component was likely to have little effect as a driver of deforestation in that area. All in all, the evidence suggests that shifting agriculture was widespread within the protected area, particularly in the period 2014-2017. However, the political and socioeconomic circumstances that led to a deforesta- 
tion peak in Los Haitises and surroundings remain unknown. Future research may provide insights into the specific causes that explain this peak in shifting agriculture, and may also provide guidelines on how to prevent the recurrence of deforestation peaks in the future, given that Los Haitises is an important protected area of the country.

440 It is worth mentioning that, in this part of the DR, another probable source of deforestation without burning is the frequent renewal by cutting of palm trees in a large plantation situated just south of Los Haitises - a typical case of commodity-driven deforestation. Although this plantation is outside the boundaries of the national park, its impact on the biodiversity and ecology of the area 445 is unknown.

Finally, in the easternmost region, much of the forest loss activity was probably driven by the expansion of tourism facilities, and by increased agricultural and livestock activities, ultimately caused by a higher demand from tourism. This is a concerning trend for the future of the DR forests, because although the protected areas of the region are relatively well preserved, there is a lack of policies aimed at the conservation and proper management of the forests in the vicinity of tourism facilities.

Regarding spatial patterns, I also hypothesized that both forest loss and fire experienced a growing spatial autocorrelation over the study period. Although 455 a high degree of spatial autocorrelation was a common characteristic in both forest loss and fire density variables over the study period, no evidence was found to support a hypothesis of a growing autocorrelation trend. Instead, a cyclical variation of autocorrelation was the most common feature observed, which I interpret as a consequence of both deforestation recovery and droughtno drought cycles. However, further research is needed to determine the precise causes of those singular cycles.

The main limitations of this study were those imposed by the intrinsic characteristics of the data available, which are ultimately related to the data acquisition mechanisms of the optical sensors MODIS and VIIRS. Although detecting

${ }_{465}$ fires under cloud cover is virtually impossible with these sensors, I surmise that 
the impact of false negatives on yearly analyses is quite limited. Another constraint met in this study was the use of fixed-size cells for the computations of zonal statistics, which may have prevented the determination of multiscalar patterns. Therefore, future research using regular and non-regular grids as zone layers, or taking advantage of computer vision techniques, may provide insights about the significant multiscalar association patterns that may exist between forest loss and fire.

In conclusion, it should be noted that since fire is a fairly common feature associated with shifting agriculture, assessing the former is an indirect means 475 of understanding the latter, which ultimately may help prevent future impact on forest ecosystems. Therefore, proper fire assessment using remotely collected data and advanced spatial statistical techniques may inform land management policies and conservation strategies to help reduce forest loss, particularly in protected areas, mountain areas, and the vicinity of tourism hubs. The ana-

480 lytical approaches used and the results obtained in this study hold potential to assist in this task.

\section{Acknowlegements}

The author acknowledges the use of data and imagery from LANCE FIRMS operated by NASA's Earth Science Data and Information System (ESDIS) with funding provided by NASA Headquarters.

\section{References}

Anselin, L. (1995). Local indicators of spatial association-LISA. Geographical analysis, 27, 93-115. URL: https://doi.org/10.1111/j.1538-4632.1995. tb00338. $\mathrm{x}$.

Anselin, L. (1996). The Moran scatterplot as an ESDA tool to assess local instability in spatial association. In M. Fischer, H. Scholten, \& D. Unwin (Eds.), Spatial Analytical Perspectives on GIS in Environmental and SocioEconomic Sciences chapter 8. (pp. 111-125). Taylor and Francis. 
Anselin, L. (2013). Spatial econometrics: methods and models volume 4. Springer Science \& Business Media. URL: https://doi.org/10.1007/ 978-94-015-7799-1.

Anselin, L., \& Rey, S. J. (2010). Perspectives on spatial data analysis. In L. Anselin, \& S. J. Rey (Eds.), Perspectives on Spatial Data Analysis chapter 1. (pp. 1-20). Berling, Heidelberg: Springer. URL: https: //link.springer.com/book/10.1007/978-3-642-01976-0.

Bivand, R., Altman, M., Anselin, L., Assunção, R., \& Berke, O. (2017). Package 'spdep'. URL: https://cran.r-project.org/web/packages/spdep/ index.html.

Bivand, R., Hauke, J., \& Kossowski, T. (2013a). Computing the jacobian in gaussian spatial autoregressive models: An illustrated comparison of available methods. Geographical Analysis, 45, 150-179. URL: https://doi.org/10. 1111 /gean. 12008.

Bivand, R., \& Piras, G. (2015). Comparing implementations of estimation methods for spatial econometrics. Journal of Statistical Software, 63, 1-36.

URL: https : //www.jstatsoft .org/v63/i18/.

Bivand, R., \& Wong, D. W. S. (2018). Comparing implementations of global and local indicators of spatial association. TEST, 27, 716-748. URL: https: //doi.org/10.1007/s11749-018-0599-x.

Bivand, R. S., Pebesma, E., \& Gomez-Rubio, V. (2013b). Applied spatial data analysis with $R$, Second edition. Springer, NY. URL: http://www. asdar-book.org/.

Breusch, T. S., \& Pagan, A. R. (1979). A simple test for heteroscedasticity and random coefficient variation. Econometrica: Journal of the Econometric Society, (pp. 1287-1294). URL: https://doi.org/10.2307/1911963.

Cámara Artigas, R. (1997). República Dominicana: Dinámica del medio físico en la región Caribe (Geografía Física, sabanas y litoral). Aportación 
al conocimiento de la tropicalidad insular. Ph.D. thesis Departamento de Geografía Física y Análisis Geográfico Regional, Facultad de Geografía e Historia, Universidad de Sevilla. URL: https://hdl . handle.net/11441/85112.

Cano, E., \& Veloz, A. (2012). Contribution to the knowledge of the plant communities of the Caribbean-Cibensean Sector in the Dominican Republic. Acta Botanica Gallica, 159, 201-210. URL: https://doi.org/10.1080/ 12538078.2012 .696933$.

Curtis, P. G., Slay, C. M., Harris, N. L., Tyukavina, A., \& Hansen, M. C. (2018). Classifying drivers of global forest loss. Science, 361, 1108-1111. URL: https://doi.org/10.1126/science.auu3445.

Department of Economic and Social Affairs of the United Nations Secretariat (2009). The millennium development goals report 2009. URL: https ://www . un.org/millenniumgoals/pdf/MDG_Report_2009_ENG.pdf.

Dirección Nacional de Parques (1991). Plan de uso y gestión del parque nacional Los Haitises y áreas periféricas. Dominican Republic Santo Domingo: Agencia Española de Cooperación Internacional y Agencia de Medio Ambiente de la Junta de Andalucía.

Greenberg, J. A., \& Mattiuzzi, M. (2018). gdalUtils: Wrappers for the Geospatial Data Abstraction Library (GDAL) Utilities. URL: https://CRAN . R-project.org/package=gdalUtils r package version 2.0.1.14.

Hager, J., \& Zanoni, T. A. (1993). La vegetación natural de la República Dominicana: una nueva clasificación. Moscosoa, 7, 39-81. URL: https: //www . biodiversitylibrary.org/item/181315.

Hák, T., Janoušková, S., \& Moldan, B. (2016). Sustainable development goals: A need for relevant indicators. Ecological Indicators, 60, 565 - 573. URL: http://www.sciencedirect.com/science/article/pii/ S1470160X15004240. doi:https://doi.org/10.1016/j.ecolind.2015.08. 003. 
Hansen, M., Potapov, P., Margono, B., Stehman, S., Turubanova, S., \& Tyukavina, A. (2014). Response to Comment on "High-resolution global maps of 21st-century forest cover change". Science, 344, 981-981. URL: https://doi.org/10.1126/science.1248817.

Hansen, M. C., Potapov, P. V., Moore, R., Hancher, M., Turubanova, S. A., Tyukavina, A., Thau, D., Stehman, S., Goetz, S. J., Loveland, T. R. et al. (2013). High-resolution global maps of 21st-century forest cover change. Science, 342, 850-853. URL: https://doi.org/10.1126/science.1244693.

Hansen/UMD/Google/USGS/NASA (2019). Global Forest Change 2000-2018. Data Download. Available on-line http://earthenginepartners appspot. com/science-2013-global-forest/download_v1.6.html.

Hijmans, R. J. (2019). raster: Geographic Data Analysis and Modeling. URL: https : //CRAN.R-project.org/package=raster $\mathrm{r}$ package version 3.0-7.

Gesto de Jesús, E. M. (2016). Motores de deforestación en el Parque Nacional Los Haitises y uso de hábitat de anidación del Gavilán de la Española (Buteo ridgwayi), República Dominicana. Master's thesis CATIE, Turrialba (Costa Rica). URL: http://repositorio.bibliotecaorton.catie.ac.cr/ handle/11554/8601.

Kalamandeen, M., Gloor, E., Mitchard, E., Quincey, D., Ziv, G., Spracklen, D., Spracklen, B., Adami, M., Aragão, L. E., \& Galbraith, D. (2018). Pervasive rise of small-scale deforestation in amazonia. Scientific reports, 8, 1-10. URL: https://doi .org/10.1038/s41598-018-19358-2.

Kuhn, M., Wing, J., Weston, S., Williams, A., Keefer, C., Engelhardt, A., Cooper, T., Mayer, Z., Kenkel, B., the R Core Team, Benesty, M., Lescarbeau, R., Ziem, A., Scrucca, L., Tang, Y., Candan, C., \& Hunt., T. (2019). caret: Classification and Regression Training. URL: https://CRAN.R-project. org/package=caret $\mathrm{r}$ package version $6.0-84$. 
LeSage, J. (2015). Spatial econometrics. In Handbook of research methods and applications in economic geography. Edward Elgar Publishing. URL: https://doi.org/10.4337/9780857932679.

Lloyd, J. D., \& León, Y. M. (2019). Forest change within and outside protected areas in the Dominican Republic, 2000-2016. bioRxiv, . URL: https://www . biorxiv.org/content/early/2019/02/22/558346. doi:10.1101/558346. arXiv:https://www. biorxiv.org/content/early/2019/02/22/558346.full.pdf.

Mangiafico, S. (2019). rcompanion: Functions to Support Extension Education Program Evaluation. URL: https://CRAN.R-project.org/package= rcompanion $r$ package version 2.3.7.

Ovalle de Morel, E., \& Rodríguez Liriano, A. (1984). Análisis de la deforestación y la foresta en la República Dominicana. Eme Eme: Estudios Dominicanos, . URL: http://hdl.handle.net/20.500.12060/1341.

Myers, R., O'Brien, J., Mehlman, D., \& Bergh, C. (2004). Evaluación del manejo del fuego en los ecosistemas de tierras altas de la República Dominicana, Global Fire Initiative Informe Técnico. Technical Report The Nature Conservancy. URL: https://www. conservationgateway.org/Documents/ dr\%20fire\%20assessment $\% 20$ spanish.pdf.

NASA (2019a). "MODIS Collection 6" standard quality Thermal Anomalies / Fire locations (MCD14ML), processed by the University of Maryland. Available on-line from the LANCE FIRMS operated by NASA's Earth Science Data and Information System (ESDIS) platform at: https://earthdata. nasa.gov/firms.

NASA (2019b). VIIRS $375 \mathrm{~m}$ standard Active Fire and Thermal Anomalies product (VNP14IMGTML), processed by the University of Maryland. Available on-line from the LANCE FIRMS operated by NASA's Earth Science Data and Information System (ESDIS) platform at: https://earthdata. nasa.gov/firms. 
OEA (1967). Reconocimiento y evaluación de los recursos naturales de la República Dominicana. Technical Report Washington, US: OEA, 1967.

Olson, D. M., Dinerstein, E., Wikramanayake, E. D., Burgess, N. D., Powell, G. V., Underwood, E. C., D’amico, J. A., Itoua, I., Strand, H. E., Morrison, J. C. et al. (2001). Terrestrial Ecoregions of the World: A New Map of Life on Earth: A new global map of terrestrial ecoregions provides an innovative tool for conserving biodiversity. BioScience, 51, 933-938. URL: https:// doi .org/10 . 1641/0006-3568(2001)051 [0933: TEOTWA] 2 . 0. CO;2.

ONE (1982). 7mo. Censo Nacional Agropecuario 1982. Vols. 1 \& 2. Technical Report Oficina Nacional de Estadística (ONE), Secretariado Técnico de la Presidencia. URL: https ://www.one.gob.do/Multimedia/Download? $\operatorname{ObjId}=1593$.

ONE (2015). Datos georreferenciados. https://www.one.gob.do/ informaciones-cartograficas/shapefiles. Accessed: 2019-09-24.

ONE (2016). Precenso Nacional Agropecuario 2015. Informe de resultados. Technical Report Oficina Nacional de Estadística. Ministerio de Economía, Planificación y Desarrollo. URL: https://web.one.gob.do/publicaciones/2016/ informe-de-resultados-definitivos-precenso-censo-nacional-agropecuario-2015/.

Pebesma, E. (2018). Simple Features for R: Standardized Support for Spatial Vector Data. The $R$ Journal, 10, 439-446. URL: https://doi.org/10. 32614/RJ-2018-009. doi:10.32614/RJ-2018-009.

Pebesma, E. (2019). stars: Spatiotemporal Arrays, Raster and Vector Data Cubes. URL: https://CRAN.R-project.org/package=stars r package version $0.4-0$.

QGIS Development Team (2020). Qgis. http://www.qgis.org/. 
R Core Team (2020). R: A Language and Environment for Statistical Computing. R Foundation for Statistical Computing Vienna, Austria. URL: https://www.R-project.org/.

Sakamoto, Y., Ishiguro, M., \& Kitagawa, G. (1986). Akaike information criterion statistics. Dordrecht, The Netherlands: D. Reidel, 81. URL: https://doi. org/10.1080/01621459.1988.10478680.

Tennekes, M. (2018). tmap: Thematic Maps in R. Journal of Statistical Software, 84, 1-39. URL: http://dx.doi.org/10.18637/jss.v084.i06.

Tolentino, L., \& Peña, M. (1998). Inventario de la vegetación y uso de la tierra en la República Dominicana. Moscosoa, 10, 179-203. URL: https: //www.biodiversitylibrary.org/item/181376.

Tropek, R., Sedláček, O., Beck, J., Keil, P., Musilová, Z., Šímová, I., \& Storch, D. (2014). Comment on "high-resolution global maps of 21st-century forest cover change". Science, 344, 981-981. URL: https://doi.org/10.1126/ science. 1248753.

UN System Task Team on the Post-2015 UN Development Agenda (2012). Realizing the Future We Want for All. Report to the Secretary-General. United Nations New York, NY. URL: https://www .un.org/millenniumgoals/pdf/ Post_2015_UNTTreport.pdf.

Venables, W. N., \& Ripley, B. D. (2002). Modern Applied Statistics with S. (4th ed.). New York: Springer. URL: http://www.stats.ox.ac.uk/pub/MASS4 iSBN 0-387-95457-0.

Wendell Werge, R. (1974). La agricultura de tumba y quema en la República Dominicana. Eme Eme: Estudios Dominicanos, . URL: http://hdl . handle. net/20.500.12060/726.

Weston, S. (2019). foreach: Provides Foreach Looping Construct. URL: https: //CRAN.R-project . org/package=foreach $\mathrm{r}$ package version 1.4.7. 
bioRxiv preprint doi: https://doi.org/10.1101/2021.06.15.448604; this version posted November 12,2021 . The copyright holder for this preprint (which was not certified by peer review) is the author/funder, who has granted bioRxiv a license to display the preprint in perpetuity. It is made available under aCC-BY-NC-ND 4.0 International license.

Wickham, H. (2017). tidyverse: Easily Install and Load the 'Tidyverse'. URL: https://CRAN.R-project.org/package=tidyverse r package version 1.2.1.

Zweifler, M. O., Gold, M. A., \& Thomas, R. N. (1994). Land Use Evolution in Hill Regions of the Dominican Republic. The Professional Geographer, 46, 39-53. URL: https://doi.org/10.1111/j.0033-0124.1994.00039.x. 
bioRxiv preprint doi: https://doi.org/10.1101/2021.06.15.448604; this version posted November 12,2021 . The copyright holder for this preprint (which was not certified by peer review) is the author/funder, who has granted bioRxiv a license to display the preprint in perpetuity. It is made available under aCC-BY-NC-ND 4.0 International license.

\section{Appendices}

Appendix A. Supplementary data for the long-term approach

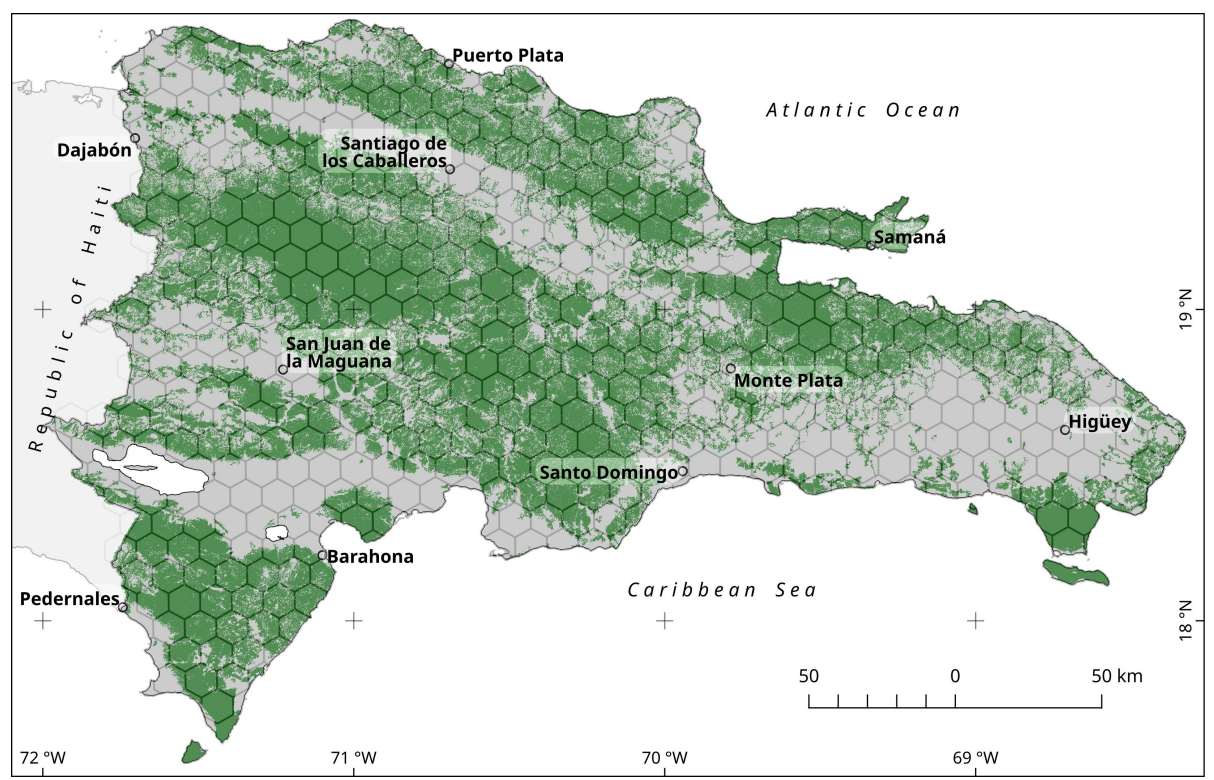

Figure A1: DR forest cover in the year 2000. Areas with a canopy closure equal to or greater than $25 \%$ in tree cover map of Hansen et al. (2013) were classified as forest. The hexagonal grid overlaid was used for zonal statistics computations of the long-term approach. See text for details. 
Table A1: Transformation parameters and normality test results for forest loss and fire variables

\begin{tabular}{|l|r|r|c|}
\hline Variable & $\begin{array}{c}\text { Tukey's Ladder of } \\
\text { Powers, } \lambda\end{array}$ & $\begin{array}{c}\text { Shapiro-Wilk test, } \\
W(p \text {-value })\end{array}$ & $\begin{array}{c}\text { Moran's } I \text { test, } \\
I(p \text {-value })\end{array}$ \\
\hline $\begin{array}{l}\text { Average forest loss } \\
\text { per unit area per } \\
\text { year (2001-2018) }\end{array}$ & $\lambda=0.33$ & $W=0.99(p=0.81)$ & $I=0.48(p \lll 0.01)$ \\
\hline $\begin{array}{l}\text { Average fire density } \\
\text { per km } \text { km }^{2} \text { per year } \\
\text { (MODIS dataset })\end{array}$ & $\lambda=0.33$ & $\begin{array}{l}W=0.98 \\
(p<0.01)\end{array}$ & $I=0.55(p \lll 0.01)$ \\
$(2001-2018)$ & $\lambda=0.23$ & $W=0.99(p=0.75)$ & $I=0.48(p \lll 0.01)$ \\
\hline $\begin{array}{l}\text { Average forest loss } \\
\text { per unit area per } \\
\text { year (2012-2018) }\end{array}$ & $\lambda=0.3$ & $\begin{array}{l}W=0.99 \\
(p<0.01)\end{array}$ & $I=0.55(p \lll 0.01)$ \\
\hline $\begin{array}{l}\text { Average fire density } \\
\text { per km }{ }^{2} \text { per year } \\
\text { (VIIRS dataset) } \\
(2012-2018)\end{array}$ & $\lambda$ & & \\
\hline
\end{tabular}

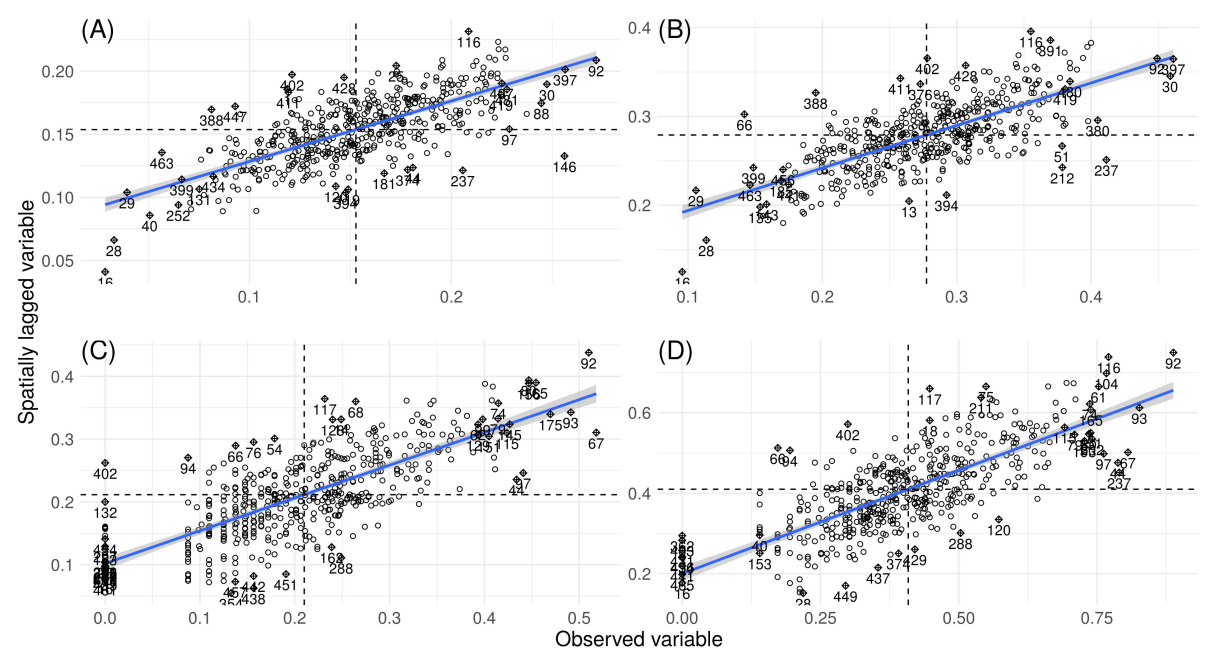

Figure A2: Moran scatterplots of the transformed versions of the analyzed variables. Average forest loss per unit area per year of the periods (A) 2001-2018 and (B) 20122018. Average number of fire points per $\mathrm{km}^{2}$ per year in the periods 2001-2018 (C), using MODIS dataset, and 2012-2018 (D), using VIIRS dataset. 
Table A2: Lagrange Multiplier tests for spatial dependence in linear regression models of forest loss as a function of fire density for the periods 2001-2018 (MODIS fire data) and 2012-2018 (VIIRS fire data)

\begin{tabular}{|l|r|r|r|r|}
\cline { 2 - 5 } \multicolumn{1}{c|}{} & \multicolumn{2}{c|}{$\begin{array}{c}\text { FORESTLOSS0118 } \\
\text { FIRESMODIS }\end{array}$} & \multicolumn{2}{c|}{$\begin{array}{c}\text { FORESTLOSS1218 }^{1} \\
\text { FIRESVIIRS }^{\dagger}\end{array}$} \\
\hline $\begin{array}{l}\text { Lagrange } \\
\text { Multiplier test }\end{array}$ & Statistic & $p$ value & Statistic & value \\
\hline $\begin{array}{l}\text { For error } \\
\text { dependence } \\
\text { (LMerr) }\end{array}$ & 330.00 & $\lll 0.01$ & 340.74 & $\lll 0.01$ \\
\hline $\begin{array}{l}\text { For a missing } \\
\text { spatially lagged } \\
\text { dependent } \\
\text { variable } \\
\text { (LMlag) }\end{array}$ & 227.22 & $\lll 0.01$ & 226.41 & $\lll 0.01$ \\
\hline $\begin{array}{l}\text { Robust variant } \\
\text { of LMerr }\end{array}$ & 106.49 & $\lll 0.01$ & 118.89 & \\
\hline $\begin{array}{l}\text { Robust variant } \\
\text { of LMlag }\end{array}$ & 3.72 & 0.05 & 4.56 & \\
\hline
\end{tabular}

${ }^{\dagger}$ FORESTLOSS0118 and FORESTLOSS1218 stand for the transformed versions of forest loss per unit-area averaged per year of the periods 2001-2018 and 2012-2018, respectively. FIRESMODIS and FIRESVIIRS stand for the transformed versions of number of fires per $\mathrm{km}^{2}$ averaged per year, detected by the MODIS sensor (2001-2018) and by the VIIRS sensor (2012-2018), respectively. 
Appendix B. Supplementary data for the annual approach

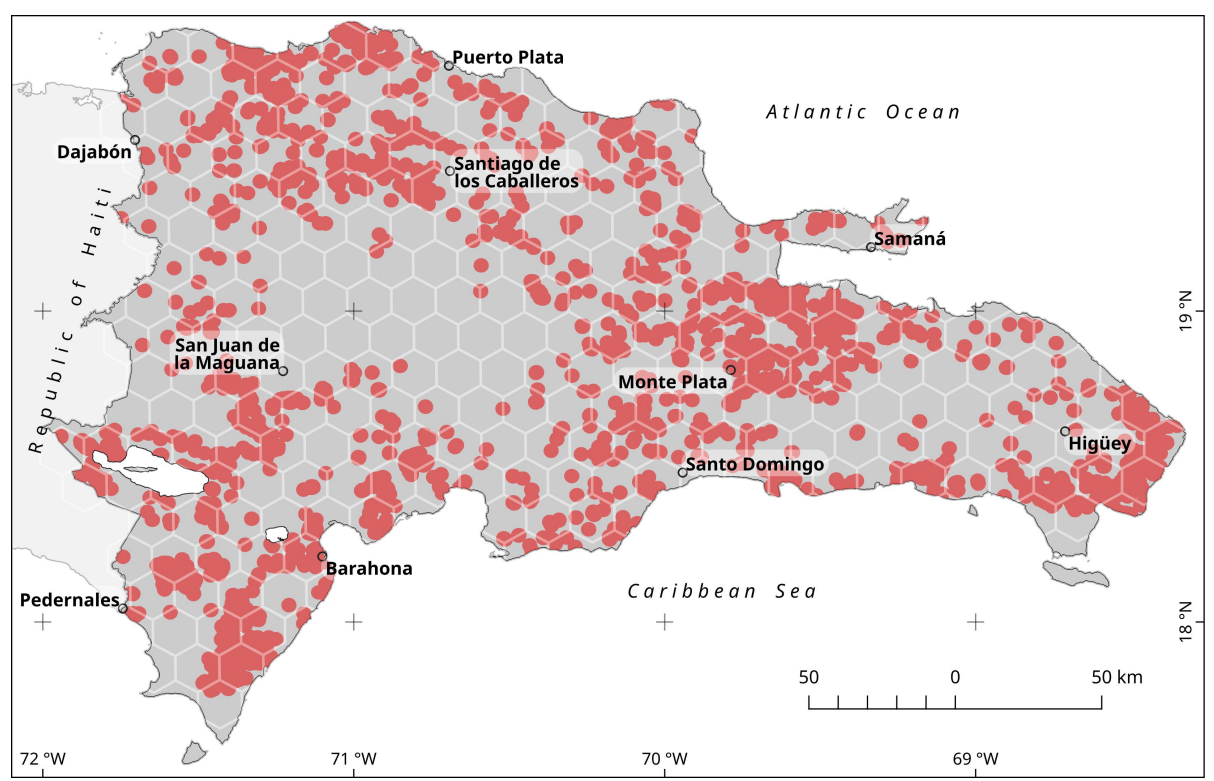

Figure B1: Example of the 2013 forest loss areas and their vicinity (red shaded areas) used in the annual trend approach. These areas were generated by adding a buffer zone of $2.5 \mathrm{~km}$ around each patch larger than 1 ha in area from the loss year dataset (Hansen et al., 2013). The hexagonal grid, depicted as an overlay, was used for zonal statistics computations. See text for details. 
bioRxiv preprint doi: https://doi.org/10.1101/2021.06 15.448604; this version posted November 12,2021 . The copyright holder for this preprint (which was not certified by peer review) is the author/funder, who has granted bioRxiv a license to display the preprint in perpetuity. It is made available under aCC-BY-NC-ND 4.0 International license.

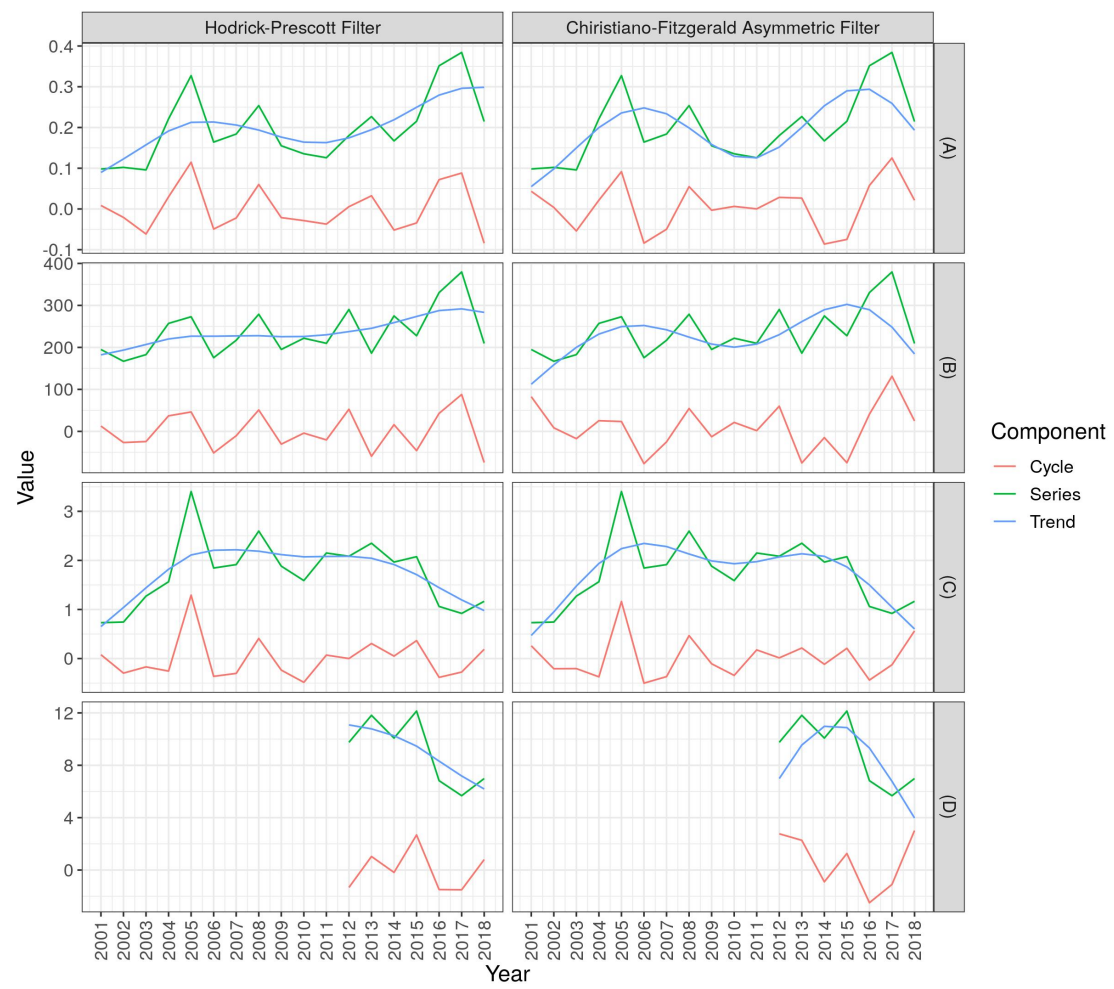

Figure B2: Time series decomposition of yearly averages per $100 \mathrm{~km}^{2}$ of (A) Forest loss area (in $\mathrm{km}^{2}$ ) of large clearings ( $>1$ ha in size); (B) Number of small clearings $(<1$ ha in size); (C) and (D) Number of fire points remotely sensed by MODIS and VIIRS sensors in or around forest loss patches 
bioRxiv preprint doi: https://doi.org/10.1101/2021.06 15.448604 this version posted November 12,2021 . The copyright holder for this preprint (which was not certified by peer review) is the author/funder, who has granted bioRxiv a license to display the preprint in perpetuity. It is made available under aCC-BY-NC-ND 4.0 International license.

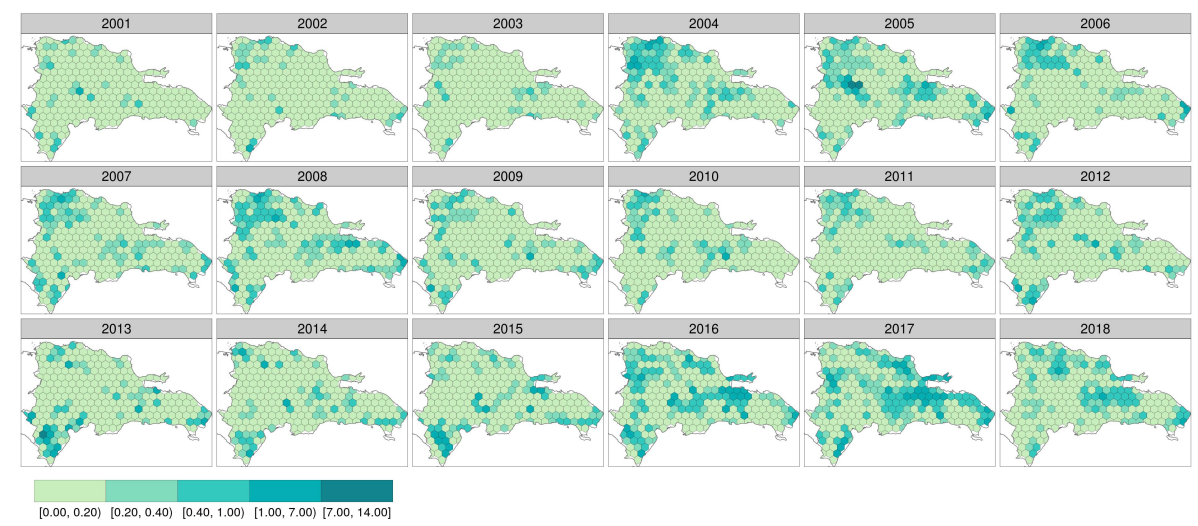

Figure B3: Yearly forest loss area (in $\mathrm{km}^{2}$ per $100 \mathrm{~km}^{2}$ ) from patches greater than $1 \mathrm{ha}$ in size for the period 2001-2018

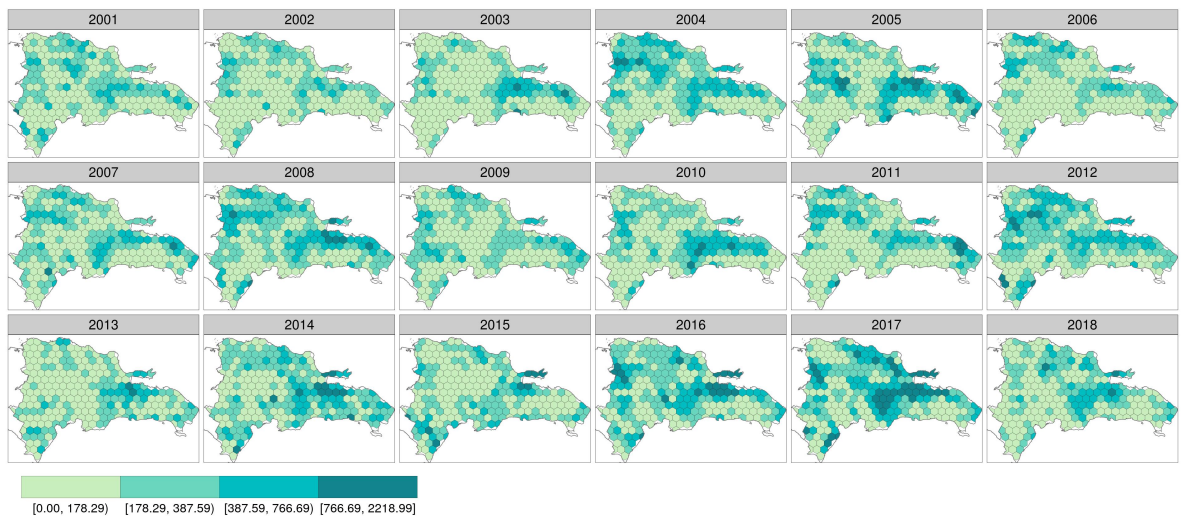

Figure B4: Yearly number of forest loss patches smaller than 1 ha (in $\mathrm{km}^{2}$ per $100 \mathrm{~km}^{2}$ ) for the period 2001-2018 
bioRxiv preprint doi: https://doi.org/10.1101/2021.06 15.448604 this version posted November 12,2021 . The copyright holder for this preprint (which was not certified by peer review) is the author/funder, who has granted bioRxiv a license to display the preprint in perpetuity. It is made available under aCC-BY-NC-ND 4.0 International license.

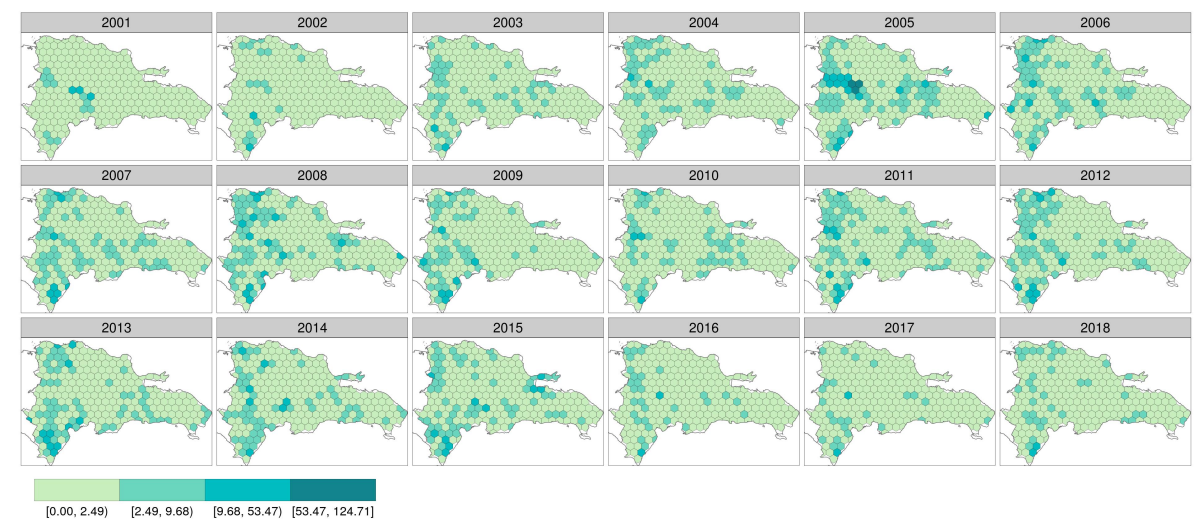

Figure B5: Yearly number of MODIS fire points per $100 \mathrm{~km}^{2}$ within patches of forest loss and surroundings for the period 2001-2018

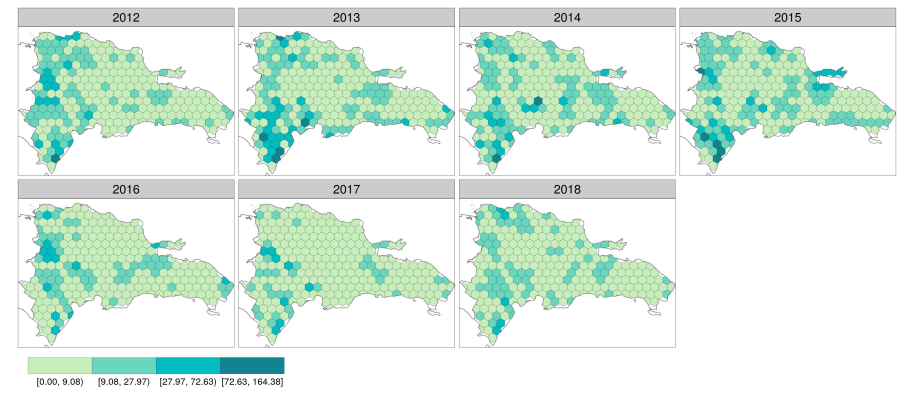

Figure B6: Yearly number of VIIRS fire points per $100 \mathrm{~km}^{2}$ within patches of forest loss and surroundings for the period 2012-2018 